\title{
Toward a Criminology of International Crime
}

\author{
MARK A. DRUMBL*
}

The criminal adjudication of those who perpetrate egregious human rights violations has gained normative currency among international lawyers and rights activists. This norm has encouraged the construction of a variety of international legal institutions, specifically tribunals and courts. This Article tracks the logic of this norm and suggests that, at its root, it represents a general extension of Western municipal criminal law, and Anglo-American common law methodologies in particular, to the international context and cases of mass violence. This triggers two interrelated concerns: is this extension (1) theoretically sustainable and (2) operationally effective for adjudicating wrongdoing in all cases of mass violence? This Article posits that important differences between municipal crime and international crime suggest that the rationalities of the former cannot so easily be proffered for the latter. Moreover, the justice that may result from this extension may be externalized from the very communities it is intended to serve. In the end, a call is made for international lawyers to structure an independent criminology for the adjudication of international crimes and to consider the relevance of communitarian and cross-cultural approaches in this regard.

\section{INTRODUCTION}

International criminal law aspires to prosecute alleged perpetrators of grievous human rights abuses. These prosecutions are to take place adversarily in criminal trials. If these alleged perpetrators are in fact found guilty, they are to be punished. Many international treaties and decisions involving state obligations with respect to gross violations of human rights speak of obligations to investigate, prosecute, and punish. ${ }^{1}$ As such, accountability is largely conflated with criminal process followed by

* Assistant Professor and Ethan Allen Faculty Fellow, School of Law, Washington \& Lee University. This Article was presented as part of the Americanization of Dispute Resolution Symposium held at The Ohio State University Moritz College of Law on November 7, 2002. I am grateful to Mary Ellen O'Connell for coordinating such an engaging symposium and to the Frances Lewis Law Center, Washington \& Lee University, for its unflagging support.

${ }^{1}$ Ronald C. Slye, The Legitimacy of Amnesties Under International Law and General Principles of Anglo-American Law: Is a Legitimate Amnesty Possible?, 43 VA. J. INT'L L. 173, 187-88 (2002); see also id. at 191 (noting that there is strong textual evidence that international law imposes a duty on states to prosecute and punish gross violations of human rights). 
punishment, which, under international criminal law, overwhelmingly takes the form of incarceration. ${ }^{2}$ Since accountability is cast as a prerequisite for justice, the criminal trial and the jailhouse become causally connected to justice as well. Furthermore, since many grievous human rights abuses are constructed as crimes against the world community - in particular, crimes against humanity and genocide-international tribunals are deemed appropriate to adjudge guilt or innocence and, in the former case, determine sentence. Moreover, breaches of international humanitarian law (the jus in bello) also fall under the aegis of international criminal law through their characterization as war crimes.

${ }^{2}$ To be sure, international law collaterally suggests that accountability can be pursued though reparations, restitution, or other forms of redress. See Stef Vandeginste, Victims of Genocide, Crimes Against Humanity, and War Crimes in Rwanda: The Legal and Institutional Framework of Their Right to Reparation, in POLITICS AND THE PAST 249, 250 (John Torpey ed., 2003) (noting that principles of reparation are contemplated by several human rights conventions but that these principles "face a rather uncertain future under international law"). These forms of accountability operate on a subaltern basis to those that evince criminal law methodologies. This subalternity arises from the paucity of international reparative entities - whether on a permanent or ad hoc basis-for postconflict societies (one example of such an institution is the United Nations Compensation Commission, which processes requests for indemnification for damages arising from Iraq's unlawful invasion and occupation of Kuwait). Moreover, within the international criminal process that has been institutionally created on an ad hoc or permanent basis, restitutionary approaches, although extant, are referenced exceptionally, on occasion, and fleetingly (and do not really form part of the law-in-practice of such institutions). See Statute of the International Criminal Tribunal for Rwanda, U.N. SCOR, 49th Sess., 3453d mtg. at 15, art. 23(3), U.N. Doc. S/Res/955 (1994), available at http://www.ictr.org/ENGLISH/basicdocs/statute.html (last visited Sept. 26, 2003) ("In addition to imprisonment, the Trial Chambers may order the return of any property and proceeds acquired by criminal conduct, including by means of duress, to their rightful owners."); Statute of the International Tribunal for the Former Yugoslavia, 827, U.N. SCOR, 48th Sess., 3217th mtg. at 29, art. 24(3), U.N. Doc. S/Res/827 (1993), available at http://www.un.org/icty/basic/statut/stat2000.htm (last visited Sept. 26, 2003) ("In addition to imprisonment, the Trial Chambers may order the return of any property and proceeds acquired by criminal conduct, including by means of duress, to their rightful owners"); Rome Statute of the International Criminal Court, U.N. Diplomatic Conference of Plenipotentiaries, at 42, art. 75, U.N. Doc. A/CONF.183/9 (1998) [hereinafter Rome Statute] (providing a mechanism for reparations to victims); International Criminal Tribunal For Rwanda Rules of Procedure and Evidence, Rule 106 available at http://www.ictr.org/ENGLISH/rules/260503/260503e.pdf (last visited Sept. 26, 2003) [hereinafter ICTR Rules of Procedure and Evidence] (referring to the national legal system of Rwanda as the vehicle through which a victim may bring an action for compensation); Vandeginste, supra, at 253 (noting that in none of the judgments passed by the ICTR has the tribunal made use of its authority to order restitution). 
All this, in turn, has prompted institution building. At the international level, there has been a proliferation of new institutions, such as the International Criminal Court (ICC), the ad hoc tribunals for Rwanda (International Criminal Tribunal for Rwanda, hereinafter ICTR) and the former Yugoslavia (International Criminal Tribunal for Yugoslavia, hereinafter ICTY), special courts (such as in Sierra Leone and Cambodia), ${ }^{3}$ and hybrid (U.N./domestic) initiatives (as in Kosovo and East Timor). ${ }^{4}$ Reconstructive efforts in Afghanistan and Iraq may also bring international legal process and personnel into play.

Furthermore, this normative preference for criminal process has also percolated to the national level, where some municipal courts are exercising universal jurisdiction to prosecute crimes committed extraterritorially. ${ }^{5}$ More

${ }^{3}$ Elizabeth Becker, U.N. Revives Plan to Try Remnants of Khmer Rouge in Cambodia, N.Y. Times, Nov. 21, 2002, at A8. From 1975 to 1979, the Khmer Rouge massacred approximately 1.7 million Cambodians. See Mark A. Drumbl, Legal Issues, in A Global AGenda: IsSues Before the 54TH General AsSEMbly of THE UNITED NATIONS 239, 278 (John Tessitore \& Susan Woolfson eds., 1999).

${ }^{4}$ In September 1999, militia forces supported by the Indonesian army massacred thousands of East Timorese and engaged in a widespread campaign of property destruction, rape, and sexual enslavement. This violence was triggered by a plebiscite in East Timor that lopsidedly supported the region's independence from Indonesia. Following the massacres, the Indonesian administration of East Timor collapsed. East Timor became independent on May 20, 2002. A transitional U.N. administration guided this process. The Security Council established the United Nations Transitional Administration in East Timor (UNTAET). Under the aegis of UNTAET, a number of regulations relating to the administration of justice have been promulgated. These established a number of district courts and one appeals court for East Timor. The Dili District Court is vested with exclusive jurisdiction over the entire territory of East Timor with respect to the six most serious offenses. See On the Organization of Courts in East Timor, UNTAET Reg. 2000/11 (Mar. 6, 2000). These are genocide, war crimes, crimes against humanity, torture, murder, and sexual offenses (the latter two crimes are prosecuted under the Penal Code of East Timor, the former crimes under universal jurisdiction). See On the Establishment of Panels with Exclusive Jurisdiction Over Serious Criminal Offenses, UNTAET Reg. 2000/15 (June 6, 2000). Special panels of three judges of mixed national and international provenance have been established to prosecute these serious offenses in the Dili District Court. Id. A number of indictments have been issued and proceedings undertaken.

${ }^{5}$ See, e.g., Vandeginste, supra note 2, at 266-69 (discussing extraterritorial litigation involving Rwanda); The Cairo-Arusha Principles on Universal Jurisdiction in Respect of Gross Human Rights Offences: An African Perspective (Oct. 21, 2002) (document on file with author) (providing that states have a responsibility and duty to prosecute, extradite or transfer for trial persons suspected or accused of gross human rights violations under international law and that this is not relieved by the use of truth and reconciliation commissions). The Belgian courts have been active in criminal prosecutions for extraterritorial human rights abuses under universal jurisdiction; U.S. courts have been 
pervasively, though, this preference may become ensconced at the national level in cases of assertions by national courts of territorial or national jurisdiction over alleged international crimes insofar as national courts may be encouraged to adopt prosecutions and procedures that look much like those at the ICC in order to minimize the risk of ceding jurisdiction to the ICC through application of the complementarity principle as set out in article 17 of the Rome Statute. ${ }^{6}$ In this vein, complementarity may encourage

active in awarding civil damage awards for jus cogens violations (in the human rights area) that take place against "aliens" outside the United States (under the Alien Tort Claims Act and the Torture Victim Protection Act, 28 U.S.C. \& 1350 (1993),for example). To be sure, the scope of the Belgian municipal law was successfully challenged before the International Court of Justice (ICJ). Arrest Warrant of 11 April 2000 (Congo v. Belg.), 2002 I.C.J. 121 (Feb. 14). However, the ICJ decision invalidated a Belgian arrest warrant on the basis of immunities; it did not repudiate the underlying universal jurisdiction. Id.

${ }^{6}$ Rome Statute, supra note 2 , at 12 , art. 17 ; see also id. at 14 , art. 20(3) (circumscribing the ne bis in idem principle when it comes to an individual tried by another court for allegations falling within the jurisdictional scope of the ICC). For a discussion of how the principle of complementarity intrinsic to the ICC may dissuade states from deploying restorative justice mechanisms such as truth commissions, see Jennifer J. Llewellyn, A Comment on the Complementary Jurisdiction of the International Criminal Court: Adding Insult to Injury in Transitional Contexts, 24 Dalhousie L.J. 192, passim (2001); see also Mohamed M. El Zeidy, The Principle of Complementarity: A New Machinery to Implement International Criminal Law, 23 MiCH. J. INT'L L. 869, 940-45 (2002) (discussing the interface between the complementarity principle and both good faith and bad faith national amnesties and pardons). Llewellyn concludes this would add "insult to already existing injuries in countries undergoing transition from pasts marred by gross violations of human rights." Llewellyn, supra, at 192. On the other hand, article 53 of the Rome Statute affords the Prosecutor some discretion in the determination whether to investigate or prosecute. Rome Statute, supra note 2, at 27-28, art. 53. Professor Leila Sadat helpfully notes that this provision was included in the Rome Statute to shield initiatives such as the South African Truth and Reconsciliation Commission from being trumped by the ICC. See Leila Sadat, Comments at the Americanization of Dispute Resolution Symposium, The Ohio State University Moritz College of Law Symposium (Nov. 7, 2002) (notes on file with author). This, too, is the position of Secretary-General Annan, who has clearly stated that the ICC would not oust national initiatives like South Africa's, where "[i]t is inconceivable that ... the Court would seek to substitute its judgement for that of a whole nation which is seeking the best way to put a traumatic past behind it and build a better future." See Press Release: Secretary-General Urges 'Like-Minded' States to Ratify Statute of International Criminal Court, U.N. Doc. SG/SM/6686 (1998) available at http://www.un.org/News/Press/docs/1998/19980901.sgsm6686.html (last visited Sept. 26, 2003). Although there may be consensus that Prosecutorial discretion would preserve the South African Truth and Reconsciliation Commission in particular, the incentive remains to model national procedures on the ICC process in order to minimize the risk of being ousted by the ICC, or of relying on discretionary exceptions to the presumption of 
heterogeneity in terms of the number of institutions adjudicating international crimes but homogeneity in terms of the process they follow.

The imperative to adjudicate international crimes and the concomitant proliferation of criminal justice institutions are largely viewed in a celebratory sense by international criminal lawyers. Furthermore, the community of international human rights activists has "adjusted its historic predisposition for the rights of the defense and the protection of prisoners to a more prosecution-based orientation." " Members of this community, too, have become partisans of the expansion of the international criminal justice paradigm. International criminal lawyers are certainly influenced by the general behavior of the wider epistemic community of international lawyers. In this regard, Benedict Kingsbury wisely points out that "it is an article of faith among most international lawyers that the growing availability and use of international tribunals advances the rule of law in international relations." 8 Global rule of law is becoming increasingly coincident with international criminal justice.

It is time to reexamine our faith. In this vein, I posit that this celebration-perhaps conveniently, perhaps unwittingly, and in all cases somewhat ritualistically through incantation-has glossed over more serious concerns and has stalled the posing of more difficult questions. These concerns include: Why are we prosecuting? What are our goals? What are the effects of these adjudications? Why are we punishing? Although there is much to celebrate in holding systematic human rights abusers accountable for their actions, a one-size-fits-all preference for the criminal law may not always be the best way to promote accountability in all afflicted places and spaces. Accordingly, the project of international criminal justice may not be sufficiently attuned to the fact that every individual's interpretation of justice derives from a multi-layered context rooted in the local. Accordingly, there should be some room in this accountability process for alternative mechanisms, such as those that draw from restorative justice, local custom, or extrajudicial dispute resolution generally.

redressing mass atrocity through criminal trials. It is unclear how article 53 of the Rome Statute would interface with other examples of local justice, or non-criminal adjudication, in the future. In the case of Rwanda, it is unclear whether traditional extrajudicial dispute resolution, such as gacaca, would be found to constitute a genuine attempt to prosecute and, hence, fall within the scope of the complementarity proviso.

7 William A. Schabas, Sentencing by International Tribunals: A Human Rights Approach, 7 DUKE J. COMP. \& INT'L L. 461, 515 (1997).

${ }^{8}$ Benedict Kingsbury, Fonward: Is the Proliferation of International Courts and Tribunals a Systemic Problem?, 31 N.Y.U. J. INT'L L. \& POL. 679, 688 (1999). 


\section{DEVIANCE AND THE ORGANIC WhOLE}

For the most part, the structure, modalities, and methodologies of international criminal law and adjudication reflect an extension of the structure, modalities, and methodologies of municipal criminal law and adjudication. The same can be said for sentencing practices. In fact, the discipline of international criminal justice, when deconstructed, truly does not have its own theoretical foundations. Instead, it takes municipal criminal law, extends it through a positivist delegation of state power to a transnational and cross-cultural context, and applies it to selected wrongdoers, all with the seemingly self-evident justification that prosecution of such wrongdoers intrinsically is desirable.

Yet, difficulties inhere in the transplantation of municipal criminal law to the international context. One critical difficulty is as follows: whereas the municipal criminal is punished because her conduct deviates from generally accepted social norms, the perpetrator of mass violence is somewhat different. Although his conduct deviates from jus cogens norms, it may not deviate from the social norms of the place where the violence actually was committed at the time it was committed. In fact, Immi Tallgren opines, "[c]ontrary to most national criminality which is understood to constitute social deviation, acts addressed as international crimes can, in some circumstances, be constituted in terms of conforming to a norm. As a result, the refusal to commit such acts could be considered as socially deviating behaviour." 9 Moreover, "the offender is likely to belong to a collective, sharing group values, possibly the same nationalistic ideology." 10 The victim, too, is chosen because of her group membership.

Let me be clear. I am not arguing in favor of ex post facto or nullum crimen sine lege defenses; these largely have been discredited since Nuremberg. Nor am I proposing that exculpations, such as following orders or compulsion, be revitalized and purposively applied to acquit individual defendants. Rather, the point here is to inquire about the special nature of mass violence and call out for that special nature to be recognized in fashioning effective methods to promote accountability for mass criminals. Can collective violence rigorously be analyzed without considering the effects of the collective on individual behavior? In the end, Tallgren's honesty is refreshing: "[T]he basic argument is difficult to contest: criminal law that could be obeyed only by exceptional individuals is hard to justify." 11

${ }^{9}$ Immi Tallgren, The Sensibility and Sense of International Criminal Law, 13 EUR. J. INT'L L. 561, 575 (2002).

$10 \mathrm{Id}$. at 573 .

${ }^{11}$ Id. 
Moreover, Professors Laurel Fletcher and Harvey Weinstein suggest that there is a "communal engagement with mass violence" that is "not addressed by criminal trials." 12 They cite the work of a number of social scientists and psychologists-including Gustav Le Bon, Stanley Milgram, S.E. Asch, and Albert Bandura-in favor of the proposition that human beings may not always be fully in control of their actions when in the context of collective events, particularly cataclysmic events. ${ }^{13}$

I have written elsewhere that Rwanda presents a compelling example of this very disturbing phenomenon. ${ }^{14}$ In fact, Rwanda demonstrates David Luban's observation that "getting people to murder and torment their neighbors is not hard; in some ways, it turns out to be ridiculously easy."15 There was a popular animus to the Rwandan genocide-it was characterized by broad-based societal involvement and support-which criminal trials may not adequately address. ${ }^{16}$ As such, criminal law that sanctions only deviant individuals may not be exclusively or fully appropriate for individuals whose crimes were undertaken as part of an organic whole. This, in turn, may suggest that the notion of state crimes within the law of state responsibilityso controversial among many members of the International Law Commission-may not be entirely wrongheaded in its contemplation of what some derisively call "collective guilt."

All this leads to the following proposition: The international community is prosecuting crimes of mass violence without first having developed a criminology of mass violence. As Tallgren writes: "It seems that in the current project of international criminal justice, the special circumstances of the criminality in question and thereby also the additional difficulties in affecting the behavior of the potential criminals addressed are largely ignored or, rather, intentionally passed over in silence." 17 Also glaring is the absence of a penology for perpetrators of mass violence. ${ }^{18} \mathrm{Here}$, there simply is an assumption that isolated incarceration for defined periods of time-the

12 Laurel E. Fletcher \& Harvey M. Weinstein, Violence and Social Repair: Rethinking the Contribution of Justice to Reconciliation, 24 HUM. RTS. Q. 573, 605 (2002).

13 Id. at 607-10.

14 Mark A. Drumbl, Punishment, Postgenocide: From Guilt to Shame to Civis in Rwanda, 75 N.Y.U. L. REV. 1221, 1246-52 (2000).

15 David Luban, Intervention and Civilization: Some Unhappy Lessons of the Kosovo War, in Global Justice and Transnational Politics 79, 107 (Pablo De Greiff \& Ciaran Cronin eds., 2002).

16 See MAHMOOd MAMDANI, WhEN Victims Become KILLERS 18 (2001).

17 Tallgren, supra note 9, at 571.

18 Ralph Henham, Some Issues for Sentencing in the International Criminal Court, 52 INT'L \& COMP. L.Q. 81,82 n.2, 85, 87 (2003). 
preference of municipal criminal law-is an appropriate punishment for those responsible for the deaths of thousands. This assumption is so ingrained that there was an absence of any substantive debate on the subject of sentencing at the Rome Conference that led to the ICC, the only exception being heated discussion of the legality of the death penalty under international law. ${ }^{19}$

Assuredly, the international criminal justice paradigm can (and does) evoke a number of justificatory rationales. The two most prominent rationales, in order of prominence, are retribution and deterrence. The powerful retributive notion posits that perpetration of mass atrocity calls out for punishment because, deontologically, it constitutes "radical evil" that must be punished. ${ }^{20}$ The ICC and ad hoc tribunals are assumed to have the moral right to inflict retributive punishment in satisfaction of the moral imperative to punish perpetrators. In practice, though, the international criminal justice paradigm cannot fully claim this as a theoretical grounding since it is only some radical evil that gets punished, whereas much escapes its grasp, often for political reasons that any moral imperative would view as anathema. Selectivity poses a challenge: Only some perpetrators in some places are prosecuted. ${ }^{21}$ Sometimes, as is the case with the ICTR, the jurisdiction of the tribunal is deliberately limited to an artificial and politically convenient time-frame. ${ }^{22}$ Selectivity also corrodes the deterrent value of such prosecutions. ${ }^{23}$ Criminologists long have posited that it is the chance of getting caught, rather than the severity of the sanction, that affects behavior. ${ }^{24}$ This is coupled with the reality that international tribunals do not

19 Id. at 85.

20 See Hannah AREndt, The Human Condtion 241 (1958); see also CaRlos SaNTIAGo Nino, RadiCAL Evil on Trial vii, ix (1996).

21 In theory, too, there are challenges. Recall Hannah Arendt's observation that even this most radical evil is, owing to its ordinary nature, banal in the places where it took place. HANNAH ARENDT, EICHMANN IN JERUSALEM 252 (rev. \& enlarged ed., Viking Press 1964) (1963).

22 Jose E. Alvarez, Crimes of States/Crimes of Hate: Lessons from Rwanda, 24 YALE J. INT'L L. 365, 397-99 (1999).

23 Deterrence fits squarely within the consequential (also called utilitarian) justification for criminal punishment. This posits that accountability for the crimes of the past may deter the commission of crimes of the future. Such deterrence may be specific to individual abusers, but also general, insofar as societies laced with accountability may also move towards democratization, rehabilitation of lesser offenders, forgiveness of victims, peace, and stability-key structural factors that allow what Mark Osiel would call the "thinking citizen" to flourish, this "thinking citizen" in turn constituting the best guard against future atrocity. See MARK J. OSIEL, MASS ATROCITY, ORDINARY EVIL, AND HANNAH ARENDT 150 (2001).

24 John Braithwaite, Crime, Shame and Reintegration 69 (1989). 
have their own police force or agents of enforcement and, as such, experience difficulty in obtaining custody over some accused. Moreover, deterrence is based on the unproven assumption of perpetrator rationality during the cataclysm of massive violence and pervasive social disequilibria.

In between deterrence and retribution lie expressive theories, which "look not so much at whether a law deters or whether a law punishes, but at the message we get from a law." 25 Here, law is posited as a reflection of "society's values, what it esteems, what it abhors." 26 Law creates norms, condemns breaches of those norms, and gives voice to changes within norms. Amann writes that expressive theories may be useful explanatory devices for the logic of international criminal justice and traces the expressive component of the Nuremberg Tribunal and the occasional expressive flavor in the judgments of the ad hoc tribunals. ${ }^{27}$ However, she also recognizes that scholarship and theoretical inquiry have not paid expressive theories much heed. ${ }^{28}$ That said, just as with deterrence and retribution, the expressive value of law is weakened by the selectivity with which it is applied. Ronald Dworkin wisely observed that "the determinacy, integrity, coherence, and 'wholeness' of law are central to its moral standing." 29 Selectivity attacks each of these attributes and thereby weakens the moral messaging and normative expressiveness of the legal function. Expressive value is further assailed-as I explore below-by the reality that this value often is externalized from afflicted local communities owing to the distance and mistrust evident between such communities and the machinery of international criminal justice.

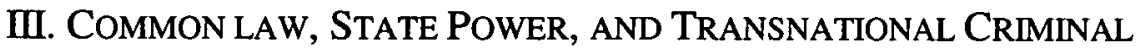 ADJUDICATION}

A second difficulty that inheres in the transplantation of municipal criminal law to the international context derives from the fact that the sources of municipal criminal law that animate international criminal justice institutions largely flow from the retributive justice paradigm as anchored in Western legal systems. Rama Mani remarks that transnational justice

25 Diane Marie Amann, Message as Medium in Sierra Leone, 7 ILSA J. INT'L \& COMP. L. 237, 238 (2001).

${ }^{26}$ Diane Marie Amann, Group Mentality, Expressivism, and Genocide, 2 INT'L CRIM. L. REv. 93, 118 (2002).

27 Id. at $121-124$.

$28 \mathrm{Id}$. at 121.

${ }^{29}$ Robin West, Taking Moral Argument Seriously, 74 CHI.-KENT L. REV. 499, 500 (1999) (citing Dworkin). 
evidences a predominance of Western-generated theories and an absence of non-Western philosophical discourse. ${ }^{30}$ There is "a troubling imbalance or 'injustice' in the study of justice," she observes. ${ }^{31}$ "[I]nternational lawyers ... have largely referred to and replicated their own legal systems, rather than catered to and built on local realities and needs." 32 In this regard, the content and process of international criminal law reflect the distribution of power in international relations. This means there is a political contingency to that which is presented as a universal methodology to account for those who inflict mass atrocity.

Within this Western legal family, I posit that Anglo-American common law approaches exert a somewhat disproportionate influence in the structure and functioning of international criminal law and adjudication. ${ }^{33}$ Many examples can be drawn from the structure and process of the ad hoc tribunals (assuredly, this discussion proceeds at a high level of abstraction, although this often is necessary for the purposes of comparative legal analysis). These include: the use of precedent and inductive reasoning in reaching decisions; the adversarial process; ${ }^{34}$ the availability of the plea bargain; 35 extensive cross-examination; no investigating or inquisitorial magistrate; the role (and provenance) of defense counsel and of amici; the absence of procedural

30 Rama Mani, Beyond Retribution: SeEking Justice in the Shadows of War $47-48,48$ n. 128 (2002).

31 Id. at 48 .

32 Id. at 81 .

33 To be sure, there is considerable heterogeneity among Anglo-American common law approaches: for example, whereas in Canada prosecutorial appeals are permitted, these are unconstitutional in the United States. International criminal process permits prosecutorial appeals. In a similar vein, most common law countries other than the United States tend to give juries a tightly circumscribed role or no role at all. As such, the fact that the ad hoc tribunals have no juries can be viewed as fully consonant with the national systems of many common law countries.

34 Vladimir Tochilovsky, Globalizing Criminal Justice: Challenges for the International Criminal Court, 9 GLOBAL GOVERNANCE 291, 294 (2003).

35 Although the ad hoc tribunals began their operations by viewing plea bargains with disfavor, this approach changed over time. For example, Rule $62 \mathrm{bis}$ of the ICTR Rules of Procedure and Evidence was adopted, permitting plea bargaining. ICTR Rules of Procedure and Evidence, Rule 62 bis, available at http://www.ictr.org/ENGLISH/rules/ 260503/260503e.pdf (last visited Sept. 26, 2003). Plea bargaining has created some confusion among defense counsel at the ICTY. Tochilovsky, supra note 34, at 294 (citing Prosecutor v. Erdemovic, IT-96-22-A, Defence's Brief Concerning Preliminary Issues, May 16, 1997). In the Rwandan national trials, plea bargaining also is incorporated and actively supported by the Rwandan government; this, too, can be cast as a penetration of common law methodologies into the domestic process of the genocide trials. 
rights for victims to become involved in the proceedings; ${ }^{36}$ and also staffing and personnel appointments. ${ }^{37}$

To be sure, there are some indicators of Western civil-law influence. The situation is, after all, not hegemonic. Civil-law influence is found in the structure of the sentencing hearings-which are added onto the main proceeding-unlike in common law jurisdictions, where there is a separate sentencing hearing. This influence is also found in evidentiary rules in which evidence, such as hearsay, is broadly admitted but then concerns over reliability attach to weight. Moreover, these civilian influences are in an expansionary phase, particularly in light of recent concerns that common law criminal trials may be susceptible to grandstanding and politicization.

As a further step in this process of evolution, the ICC differs from the ad hoc tribunals in a number of important ways. Many of these differences reflect the fact that the ICC incorporates more civil law methodology than do the ad hoc tribunals. In fact, Professor Sadat observes that the ICC may be more of an equal mix of the two Western legal families. ${ }^{38}$ For example, the ICC creates space for an inquisitorial magistrate, which takes the form of the pre-trial chamber. ${ }^{39}$ The fact that the ICC looks less like a common law institution than the ad hoc tribunals may in part derive from the reduced scope of U.S. influence over its constitutive process, ${ }^{40}$ although other common law countries certainly remain influential.

36 Tochilovsky, supra note 34, at 294.

37 Although common law legal systems reflect a minority of the world's legal systems, common law lawyers occupy a disproportionate number of influential appointments in international criminal law institutions. See Tochilovsky, supra note 34, at 294. One striking example involves the Special Court for Sierra Leone, in which most senior officials come from the U.S. and U.K. legal systems. See also id.

38 See Sadat, supra note 6.

39 The ICC also moves toward polycentric understandings of justice, for example with the acknowledgement of a reparative remedy that goes beyond the restitution contemplated (but not yet put in practice) by the ad hoc tribunals. See Rome Statute, supra note 2 , at 42 , art. 75 .

40 The United States has played a catalytic role in the formation of international criminal tribunals, particularly the ad hoc tribunals, and also in the history of war crimes proceedings, with Nuremberg as the classic example. It is self-evident that the United States has a troubled relationship with the ICC. Although the United States may deem it in its national interest for the ICC to intervene on a discretionary basis in some places, the United States resists its permanent nature and the ability for the ICC to investigate wrongdoing in the United States outside the gatekeeping of a Security Council veto. John Quigley argues that this gives rise to a curious pathology: While the United States is devoted to the rule of law, the United States believes it is above the rule of law. See John Quigley, Comments at the Americanization of Dispute Resolution Symposium, The Ohio State University Moritz College of Law (Nov. 7, 2002) (notes on file with author). This 
Still, when the entire package of international criminal justice is unwrapped, it remains a reflection of the values of Western retributive criminal justice, which-for the moment at least-disproportionately are being enforced through common law methodologies, with or without U.S. participation. However, regardless of the balance of influence between the common law and the civil law, one much more relevant fact remains clear. While international criminal justice institutions appear to have gone some way toward reconciling adversarial and inquisitorial procedural approaches, this reconciliation reflects a diplomatic bargain and pragmatic compromise among powerful international actors, not a genuine communitarian amalgam that accommodates the disempowered victims of mass violence lacking a voice in international relations.

In the end, the international community may be increasingly willing to subject the conduct of the human rights abuser to adjudication. This is, however, a narrow form of judicialized adjudication limited largely to retributive criminal punishment corresponding to Western-driven process and not a broader form of adjudication that includes restorative initiatives, local values, the needs of victims, rectification, restitution, collective and foreign responsibilities, distributive justice, and penetrating questions about the structural nature of violence in the international system. What we have done is eradicated impunity for some evildoers in some places. We thereby remove that "filth" from sight or smell.41 Yet this conveniently or unwittingly obfuscates the myriad structural factors that permitted the evildoer to perpetrate evil on such a large scale. What we have not thoroughly done is examine the correlation between these structural factors and the long-term peaceful resolution of disputes within and between afflicted societies. If the criminal justice approach becomes presumptive-not to mention absolutethen it may dissuade, or even squeeze out, the formulation of alternate approaches to accountability that may have more meaning to local lives, offer more searching explanations for mass violence, and help build a

pathology may infect the legitimacy of international criminal law in the myriad places subject to that law. I have argued elsewhere that this pathology animates the treatment of Guantanamo Bay detainees, which is to be contrasted with firm U.S. support for rigorous due process for prosecutions regarding mass atrocity in Rwanda, the former Yugoslavia, and Cambodia. Mark A. Drumbl, Victimhood in our Neighborhood: Terrorist Crime, Taliban Guilt, and the Asymmetries of the International Legal Order, 81 N.C. L. REV. 1, 92-105 (2002). Also demonstrative of these inconsistencies is Professor Antonia Handler Chayes's observation that, whereas the United States has taken a lead in encouraging the litigious nature of the World Trade Organization, it is taking such a recalcitrant approach to the ICC. See Antonia Handler Chayes, Comments at the Americanization of Dispute Resolution Symposium, The Ohio State University Moritz College of Law (Nov. 7, 2002) (notes on file with author).

41 OsIEL, supra note 23 , at 157. 
cosmopolitan and cross-cultural criminology for international crime. The end result may be less justice and accountability. To some extent, Rwanda constitutes a case study of this phenomenon. In Rwanda, traditional community dispute resolution (gacaca) has been heavily criticized by Western activists for lacking in due process, but it may offer the only viable method that can allocate some responsibility, promote reintegration, and actually mesh with local conceptions of justice. ${ }^{42}$ Moreover, gacaca may provide the only plausible mechanism to distribute reparations (and hence diversify the legal response to the Rwandan genocide), which the Rwandan government is endeavoring to provide at the national level with very limited assistance by international audiences or the ICTR. ${ }^{43}$

Massive human rights abuses torment at two levels. They are committed locally by local populations against other local populations. At the same time, they constitute a concern of the international community at large. At the end of the day, however, I believe that those victimized by the violence must have the final word on how to account for their tormentors. Arguably, accountability as presently understood may prompt a cathartic vindication for survivors of human rights abuses and some sense of solace for the loved ones of those victimized, and thereby serve utilitarian goals. ${ }^{44}$ However, when the process by which accountability is meted out is distant from or alien to local populations, then disconnects arise and justice becomes externalized. When justice is externalized from the afflicted societies for which it was intended, then it becomes more difficult for any of the goals of prosecuting and punishing human rights abusers-whether denouncing radical evil, expressing values, building new societies, voicing retribution, or preventing recidivism - to take hold. Just because an institution is international does not mean ipso facto that it is better or more legitimate in local eyes. An

42 The Rwandan government has enacted gacaca legislation that contemplates processing up to 40,000 of the 115,000 individuals detained in Rwandan jails on genocide-related charges. See Rwanda to Release 40,000 Genocide Suspects, THE GLOBE AND MAIL, Jan. 8, 2003, at A10. It is important to underscore that gacaca also has been criticized by some victims groups in Rwanda. Id. For a broader discussion, see Drumbl, supra note 14, at 1263-67.

43 Vandeginste, supra note 2, at 253-54, 258-62. In fact, the government of Rwanda wanted the ICTR to consider allowing civil claimants to be involved in the trials and to have the power to award damages when it was found to be appropriate, but this did not bear fruition. Id. at 254 .

44 See Lloyd L. Weinreb, Desert, Punishment, and Criminal Responsibility, 49 LAW \& CONTEMP. PROBS., 47, 79 (1986). 
international institution such as the ICTR may in fact constitute "a rather distant reality."45

Sensitivity to local meaning can ensure that deontological denunciation resonates with lives lived locally, and that the behavior that is sought to be deterred actually is deterred in a manner that activates local cultures-these being the environments in which law matters most and in which all abuses occur. Moreover, in terms of the expressive value of law, Diane Amann is wise to point out that "[t]he message understood, rather than the message intended, is critical." 46 In this sense, I argue that taking local community standards into account pertains to each of the deontological, retributivist, expressive, and consequential goals of punishment. When law is supported by community consensus it will serve as a viable filter for the condemnation of that community, as well as the expressiveness of the legal function. ${ }^{47}$ Looking ahead toward the reconstructive function, Dan Kahan postulates that criminal law may play some role in the development of social norms. ${ }^{48} \mathrm{I}$ would add that, in order to do so even modestly, it must be hooked into preexisting values and must be communicated in language that resonates among local populations in a manner that is familiar.

\section{DISSIDENT VOICES}

Some dissident voices challenge the seemingly self-evident rationale for international justice as implemented through Western-style criminal trials. These voices inquire whether a uniform criminal justice response should be institutionalized as a presumptive and universal response to mass violence everywhere, or whether space should be kept for individuated, pluralistic, or locally-defined justice that may differ from the modalities of Western criminal justice. ${ }^{49}$ Other voices challenge the animus behind international

45 John Torpey, Introduction, in POLITICS AND THE PAST 1, 22 (John Torpey ed., 2003).

46 Amann, supra note 25, at 238.

47 See Paul H. Robinson \& John M. Darley, The Utility of Desert, 91 Nw. U. L. REV. 453, 481 (1997); for a general discussion on expressivism, see Elizabeth S. Anderson \& Richard H. Pildes, Expressive Theories of Law: A General Restatement, 148 U. PA. L. REV. 1503, 1506-08 (2000).

48 See Dan M. Kahan, The Secret Ambition of Deterrence, 113 HARV. L. REV. 415, 432 (1999).

49 See generally MARTha Minow, BetweEn VENGEANCE AND ForgIVENESS, passim (1998); see also Drumbl, supra note 14, at 1324. Reference is often made here to the South African example, in which a mixture of criminal prosecutions (and the threat thereof), amnesties, reparations, opportunities and services, and public inquiries were 
criminal justice, deconstructing it as "a religious exercise of hope" that "just feels right" whose purpose is a "soothing strategy" so that the international community can "measure the immeasurable." 50 Some query whether international criminal justice simply is convenient-in a manner similar to municipal criminal law-as it places blame for criminal violence on selected savage individuals instead of offering a more complete explication of the myriad political, economic, historical, and colonial factors that facilitate the violence. ${ }^{51}$ Others fret about the effects of the criminal trial on reconciliation and reconstruction in post-conflict societies: although the trial may represent "closure," this "closure" may be chimeric, insofar as the smoke and mirrors of "closure" may divert attention from broader-based reconstruction efforts or lure us into forgetting that criminal trials cannot address many of the causes of the violence. 52 These scholars are closely tracked by others who suggest that criminal trials represent only a first step, but do not effect rectificatory or distributive justice and, as such, offer a panacean, but deceiving, quality as, in fact, they only supply a partial print of justice..$^{53}$ Another group challenges the prevailing orthodoxy of international criminal justice that collective guilt is to be eschewed ${ }^{54}$ and that individuated criminal guilt deters future wrongdoing by others. ${ }^{55}$ Some worry that a too unyielding emphasis on criminal process can undermine political stability. ${ }^{56}$ Some argue

used in the country's transition from apartheid. Gershwin Wanneburg, S. Africa Plans Payment to Apartheid Victims, Reuters (document on file with author).

50 Tallgren, supra note 9 , at 561, 593; see also Alvarez, supra note 22, at 460-61 (arguing that the ICTR represents the pursuit of an international political and liberallegalist agenda less helpful to Rwanda than joint initiatives within Rwanda itself would have been).

51 See OSIEL, supra note 23, at 157; Makau Mutua, Savages, Victims, and Saviors: The Metaphor of Human Rights, 42 HARV. INT'L L.J. 201, 201 (2001).

52 Alvarez, supra note 22, at 436-52 (arguing that normative ideals such as ethnic neutrality and the supposed superiority of international legal norms and expertise over local justice may in fact lead to a trial process that does not accord with the needs of victims or the victimized society); see also José E. Alvarez, Rush to Closure: Lessons of the Tadic Judgment, 96 MiCH. L. REV. 2031, 2112 (1998).

53 See MANI, supra note 30, at 9-11.

54 See MAMDANI, supra note 16 , at 17-18; Fletcher \& Weinstein, supra note 12 , at 604.

55 See Tallgren, supra note 9, at 561, 569-70.

56 Steven Erlanger, Did Serbia's Leader Do the West's Bidding Too Well?, N.Y. TIMES, Mar. 16, 2003, at WK4.

[T] here are larger questions about the price the prosecutors at The Hague-and behind them, the leaders of the United States and Europe-are asking from a shaky democratic leadership of a poor and corrupted state. Western notions of guilt and innocence, already perceived as "victor's justice" by many in the Balkans, have put 
there is a place for "just amnesties" in the transitional process given that it is a particular (and narrow) conception of justice that underscores the common assumption that amnesty is antithetical to the pursuit of justice. ${ }^{57}$

Dissident voices also can be heard outside the legal academy. For example, political scientists William Long and Peter Brecke have recently conducted systematic research on ten societies roiled by civil conflict. ${ }^{58}$ They conclude that lasting social order is restored by a "forgiveness process characterized by truth telling, redefinition of the identity of the former belligerents, partial justice, and a call for a new relationship." 59 Assuredly, criminal trials may form an element of partial justice. ${ }^{60}$ However, they may do little to foster these other equally important goals. All things considered, the international criminal justice project may accord insufficient attention to empirical work-particularly that conducted by non-lawyers-and instead accepts as a mantra the social engineering role of criminal process. This is disappointing insofar as it is precisely this sort of empirical work that can ground a criminology for mass violence, along with practical prescriptions about how best to build institutions that can spur salutary and constructivist results.

To be sure, many dissident scholars found a clearer voice once international criminal tribunals, principally the ICTR and ICTY, started to issue judgments. The curative powers of these tribunals began to come under fire when disconnects were revealed between the work of the tribunals and the societies whose health they were to nurture. ${ }^{61}$ These disconnects reveal the ugly fact that the alleged legitimacy of international institutions is not always apparent to local populations, and that there are times and places where "inferior" local institutions should not be trumped by "superior" international ones. Accordingly, these voices are rooted not narrowly in theory, but also in experience and narrative. As I argued earlier, many of these disconnects represent the externalization of justice away from victim

an enormous strain on the fledgling democratic governments of Croatia and Montenegro, too.

Id.

57 See generally Slye, supra note 1.

58 See generally WiLliAM J. LONG \& PETER BRECKE, WAR AND RECONCILIATION (2003).

${ }^{59}$ Id. at 3 (conducting case studies in Colombia, North Yemen, Chad, Argentina, Uruguay, Chile, El Salvador, Mozambique, South Africa, and Honduras).

60 Id. at 71.

61 Erlanger, supra note 56, at WK4 (reporting that "the West squeezed [former Serbian Prime Minister] Mr. Djindjic to death in a too-tight embrace of specific demands for... extradition of war criminals ... and tied the delivery of desperately needed foreign aid to those conditions"). 
communities. The extension of Western criminal process is an important driving force behind the normalization of this methodological externalization.

I am not saying that cultural relativism prevents us from establishing a system-wide norm that those who perpetrate great evil should be held accountable. No human being wants to be the victim of great evil; no society views the infliction of such evil as something that should be tolerated. But how that accounting is made and how that accountability is established are central concerns. The operationalization of accountability determines its legitimacy. It is here that concerns regarding externalization emerge. When the meaning of international judgments becomes externalized from the afflicted communities, then the procedure and act of judging becomes little more than a symbol or a rite, perhaps undertaken for the benefit or purification of the international community rather than for the reconstruction of the terrorized society.

Regardless of the upshot, "[i]f ideas and institutions about as fundamental and personal a value as justice are imposed from the outside without an internal resonance, they may flounder, notwithstanding their assertions of universality." 62 Such is precisely the case in Rwanda, where Rwandans largely remain ambivalent or at times cross with the ICTR, whose trials are largely inaccessible, alien, and have minimal impact on the victims' lives and offer a marginal dent in the volume of overall defendants. ${ }^{63}$

In the end, these dissident voices are having some influence on the future development of international criminal justice. In recent years, there have been some efforts to better involve the local in pre-existing international institutions. ${ }^{64}$ There also has been some movement toward diversifying the

62 MANI, supra note 30 , at 49.

${ }^{63}$ Id. at 99 . Rwanda initially voted against the creation of the ICTR, in part because of its location outside of Rwanda. Alvarez, supra note 22, at 393 . The Rwandan government had expressed a preference for trials in Rwanda. $1 d$.

64 To varying degrees, both the ICTR and the ICTY are working on joint ventures with national courts, although these have not yet reached the implementation stage. Recent developments at the ICTY are particularly instructive. See Press Release, ICTY, Joint Preliminary Conclusions of OHR and ICTY Experts Conference on Scope of BiH War Crimes Prosecutions, OHR/PIS/723-e (Jan. 15, 2003), available at http://www.un.org/icty/pressreal/2003/p723-e.htm (last visited Sept. 26, 2003). ICTY President Judge Jorda has indicated interest in referring some cases to national courts, in the first instance a special chamber to try serious violations of international humanitarian law in the State Court of Bosnia and Herzegovina. Press Release, ICTY, Address By His Excellency, Judge Claude Jorda, President of the International Criminal Tribunal for the Former Yugoslavia, to the United Nations Security Council, JDH/P.I.S./690-e (July 26, 2002) [hereinafter July 26, 2002 Press Release], available at http://www.un.org/ icty/pressreal/p690-e.htm (last visited Sept. 26, 2003). On September 30, 2002, the ICTY 
legal responses to mass atrocity. Newer institutions, such as the Special Court for Sierra Leone and UN-assisted tribunals for Kosovo and East Timor, may go some way to reflect this conceptual pluralism. ${ }^{65}$ However,

Rules were amended to allow for the ICTY to set in motion a referral process to national courts. A similar amendment has been made to the ICTR Rules of Procedure and Evidence, although ICTR officials are considerably more circumspect regarding transfers. See ICTR Rules of Procedure and Evidence, 12th Plenary Session, Rule 11 bis, available at http://www.ictr.org/ENGLISH/rules/050702/amend12.htm (last visited Sept. 26, 2003). The ICTY amendment would permit the prosecution of crimes in the former Yugoslavia to proceed through a multi-tiered structure. The most serious offenders would face the ICTY, intermediary level accused would face the State Court, and local courts would handle low-ranking accused. For the moment, though, it is unclear when and even if these reforms shall be implemented. In all cases, international primacy is preserved insofar as it is the international tribunal that decides whether or not to refer cases to national institutions, and ICTY President Jorda is quite clear that it shall be "cases of lesser importance" that are transferred and that the transfers only will begin after ICTYapproved adjudicatory institutions are established nationally. See Press Release, ICTY, Address by His Excellency, Judge Claude Jorda, President of the International Criminal Tribunal for the Former Yugoslavia, to the United National Security Council, JDH/P.I.S./708-e (Oct. 30, 2002), available at http://www.un.org/icty/pressreal/p708e.htm (last visited Sept. 26, 2003). In all likelihood, the newly created national courts will look much like the international institutions; since transfer is contingent on the satisfaction of the international institution, an incentive is created for the national institution to look and act like the international one. Control of the transfer process remains within the purview of the ICTY given that the local courts will require authorization by the ICTY in order to prosecute, especially for those cases referred by the ICTY. Id. Accordingly, the ICTY will "oversee[] the proper conduct of the ... trials." July 26, 2002 Press Release, supra. Judge Jorda notes that the ICTY

should be authorised to ensure that the accused answer before the national courts for all of the crimes in the Prosecutor's indictments, that the victims and witnesses are duly protected and, in broader terms, that the national trials are conducted in accordance with the international norms regarding the protection of human rights.

Id. Once again, there is a focus on the importance of Western-style rights discourse. Judge Jorda describes the State Court as a "national court already in place that is provisionally accorded] ... a minimal international character in order to guarantee its impartiality and independence." Id. It is unclear whether, from the perspective of Serbs, Croats, and Muslims, each of which were - to varying degrees-aggressors and victims in the Balkans conflicts, the mere fact that an institution is "international in character" is any indication of impartiality or independence. It should not be assumed that, just because something is "international," that it is "better" or perceived as "better" than something local.

65 The development of a UN-created truth commission for East Timor (which incorporates East Timorese nationals and community-based approaches) may signal the beginnings of a much-welcomed paradigmatic diversity. See On the Establishment of a Commission for Reception, Truth and Reconciliation in East Timor, UNTAET Reg. 2001/10 (July 13, 2001). However, this commission is designed to "complement" and not "replace" national or international prosecutions, thereby preserving the presumptive 
these developments are at best inchoate and fragile. Moreover, they still adumbrate the primacy of the adversarial criminal justice paradigm.

\section{CONCLUSION}

The reality that international criminal law truly does not have its own sense of why it operates is understandable given the relative youth of the field, the urgency with which it is undertaking its task, and Cherif Bassiouni's notion that this law operates within the chaotic state of nature of international relations. ${ }^{66}$ It does not follow, however, that international criminal law should shirk the construction of an operational rationale or appropriate a sense of purpose that truly is its own. To fail to do so would consign international criminal law to a perpetual stage of adolescence.

In this sense, these dissident voices may give international criminal law and adjudication its own conceptual and philosophical foundation, instead of its current grounding on borrowed stilts. After all, these dissident voices do not echo the often tired grumblings of the political realist who resists legal incursions into national sovereignty. Nor do they seek to preserve impunity, whether directly or indirectly. Instead, they view accountability for egregious human rights abuses as a terribly important goal and believe that law has a role in this process. However, an intellectually honest appraisal is needed, and such an appraisal should admit that egregious international crimes are not the same as municipal crimes.

Violent social norms do not preclude a finding that an individual's violent conduct is criminal. Nor should that ever be the case. But individual criminal trials patterned on sanctioning deviant conduct may not be the most effective way to promote accountability for violent, albeit shared, social norms. Honestly assessing the limits of criminal trials may free us from the trap of deviance and may enable us to pursue more polycentric and diverse methods to ensure accountability for a broader range of individuals in a broader array of ways.

We should welcome the uniqueness of mass atrocity and develop legal responses that derive from their own individuated jurisprudential justifications, even if these are not neat, clear, or simple. In this regard,

position of trials within the hierarchy of post-conflict justice mechanisms. See Carsten Stahn, Accommodating Individual Criminal Responsibility and National Reconciliation: The UN Truth Commission for East Timor, 95 AM. J. INT'L L. 952, 953-54, 960 (2001). Nor are the community-based mechanisms applicable to the criminal proceedings. Id. at 964.

${ }^{66}$ Cherif Bassiouni, Comments at the Paradigms of International Justice Conference, Washington University in St. Louis, School of Law (Oct. 11, 2002) (notes on file with author). 
international lawyers may wish to avail themselves of more contextual approaches, more openness, and greater pluralism. A one-size-fits-all judicial absolutism, which seems so clean and neat, may lead to disappointing results. As the impetus to globalizing criminal accountability gathers steam, some room must be carved out for local peculiarities.

The globalization of process does not free that process from an ideological underpinning. International criminal law should contemplate a communitarian underpinning, in which international norms become sedimentarily integrated into local societies in a manner that takes into account cultural needs instead of imposing cultural values. ${ }^{67}$ Ralph Henham puts it well when he argues that "the future challenge for the ICC lies in the extent to which it succeeds in developing its penality by adopting principles and approaches designed to reconcile the local with the global at the moral or normative level...to engage successfully with local mechanisms of accountability and the institutions of punishment." 68 In the end, this may allow international criminal justice to be more than just a byproduct of state power. By embracing the local and the diverse, and by welcoming the practices of the often marginalized places where mass violence occurs, international criminal law can become something that transcends such power. Without such an orientation, international criminal law may simply speak the language of and serve self-referential globalitarian interests.

${ }^{67}$ MANI, supra note 30, at 48-49, 49 n.130.

68 Henham, supra note 18 , at 90. 